\title{
THE CONTRIBUTION OF AUTHENTIC MATERIAL IN EFL CLASSROOM
}

Janeth Robinson, Freddy Nicholas and Tony Seimon*

Research Institute for Social Sciences

*Corresponding author's email: tony_seimon@riss.org

\begin{abstract}
The study investigates the contribution of authentic material on developing speaking skills in EFL classrooms. Three groups of students were formed. All studied English at the High School. Participants were assigned to groups at random. No significant differences in speaking skills could be established between the groups prior to the experiment. The control group listened to authentic audio tracks in English and discussed their contents, watched authentic English movies and did exercises based on these tasks for developing speaking skills. The first experimental group spent part of the time on theoretical explanation of, and practical exercises with, English prosody by an instructor. The second experimental group instead spent part of the time on English prosody instruction. The total instruction time was the same for all three groups, i.e. 20 hours. Students then took a posttest in speaking skills. The results showed that the second experimental group performed better than the other groups in developing speaking skills. These results have pedagogical implications for curriculum designers and all who are involved in EFL classrooms.
\end{abstract}

Key words: English as a Foreign Language (EFL), Authentic Material, Speaking Skill $\underline{\text { FULL TEXT }}$ 


\section{APA CITATION:}

Robinson, J., Nicholas, F., \& Seimon, T. (2020). THE CONTRIBUTION OF AUTHENTIC MATERIAL IN EFL CLASSROOM. Journal of Social and Humanity Sciences, 15(2), 30-50.

\section{Disclosure statement}

No potential conflict of interest was reported by the authors.

\section{References}

Amalia, R., \& Nanda, D. S. (2017). GENDER DIVERGENCE IN ENGLISH LEARNING MOTIVATION AT THE TENTH GRADE STUDENTS OF KARTIKATAMA SENIOR HIGH SCHOOL METRO. LINGUISTIKA, 8(1).

Ariyana, D., \& Nanda, D. S. (2017). AN ANALYSIS OF TEACHER STRATEGIES IN TEACHING READING COMPREHENSION AT SMA MUHAMMADIYAH 1 METRO ACADEMIC YEAR 2017/2018. LINGUISTIKA, 8(2).

Carter, R and McRae, J. (2004). Language, Literature, and the Learner: Creative Classroom Practice. England: Routledge.

Carter, R. and Long, M. (eds). (1991). Teaching Literature. London: Longman.

Collie, J. and Slater, S. (eds). (1987). Literature in the Language Classroom. Cambridge: Cambridge University Press.

Cruz, J. H. R. (2010). The Role of Literature and Culture in English Language Teaching. Linguistica, 7, 1-16.

Halliday, M.A.K. (1978). Language as social semiotic: The social interpretation of language and meaning. London: Edward Arnold.

Harmer, J. (2007). The Practice of English Language Teaching. London: Pearson Education Limited.

Hismanoglu, M. (2005). Teaching English through Literature. Journal of Language and Linguistic Studies, 1(1), 53-66.

Irene, K. V. (2015). The Use of Literature in the Language Classroom: Methods and Aims. International Journal of Information and Education Technology, 5(1), 74-79. 
Jenkins, J. (2007). English as a lingua franca: Attitude and identity. Oxford: Oxford University Press.

Jenks, E. B. (2005). Parents' stories of raising children with visual impairments in a sighted world. Journal of Contemporary Ethnography, 34, 143-169.

Khusniyah, S. U., \& Nanda, D. S. (2016). EFFECT OF USING CUE CARDS TO IMPROVE STUDENTS'SKILLS IN WRITING DESCRIPTIVE TEXTS AT THE TENTH GRADE STUDENTS OF MA MA'ARIF 06 PASIR SAKTI. LINGUISTIKA, 7(2).

Kirkpatrick, A. (2010). English as a Lingua Franca in ASEAN: A multilingual model. Hong Kong: Hong Kong University Press.

Kramsch, C. (1993) Context and Culture in Language Teaching. Oxford: Oxford University Press.

Lazar, G. (1993) Literature and Language Teaching: A Guide for Teachers and Trainers. Cambridge: Cambridge University Press.

Levy, M. (2009). Technologies in use for second language learning. The Modern Language Journal 93, 769-782.

Long, W. J. (2004). English Literature: its History and its Significance for the life of English Speaking World. Gutenberg: The Project Gutenberg EBook.

Matthiessen, C.M.I.M. (1995). Lexicogrammatical cartography: English systems. Tokyo: International Language Science Publishers.

McRae, J. (1991). Literature with a Small 'I'. London: Macmillan Publishers Ltd.

Melasari, M., Ismawati, K., \& Nanda, D. (2019). The Effect of Using Crossword Puzzle Towards Students' Vocabulary Mastery in the Eleventh Grade Students of SMA Muhammadiyah 2 Bandar Lampung in Academic Year 2017-2018. Journal of English Education Studies, 2(1), 67-73. https://doi.org/10.30653/005.201921.37

Melie, S., William, G., Susanto, S., \& Nanda, D. S. (2020, January 11). Foreign language training for visually impaired students in South East Asian countries. https://doi.org/10.31219/osf.io/vjrng

Mitchell, M. (1996). Gone with the Wind. New York: Pocket Book.

Mukhroji, M. (2020). Exploring the Academic Writing Needs to Improve the Academic Literacy of the Indonesian EFL Undergraduate and Masters Students. International Journal of Innovation, Creativity and Change, 10(10), 252-269. 
Naik, N. S. (2011). Teaching English Language through Literature. New Delhi: Sarup Book Publishers PvT.Ltd.

Nanda, D. S. (2016, May). Fostering the Use of Drama for English Language Learners in the EFL Classroom. In International Conference on Education and Language (ICEL) (p. 7).

Nanda, Deri S., and Susanto Susanto. "THE EMERGENCE OF CYBER LITERATURE: A CHALLENGE TO TEACH LITERATURE FROM TEXT TO HYPERTEXT.” EdArXiv, 21 Jan. 2020. Web.

Nanda, D. S., \& Susanto, S. (2020, August 26). Using Literary Work as Authentic Material for the EFL Classroom in Indonesia. https://doi.org/10.31219/osf.io/cjrwt.

Paran, A. (2008). The role of literature in instructed foreign language learning and teaching: An evidence-based survey. Language Teaching, 41(4), 465-496.

Putri, F. A., Salatar, B., \& SUSANTO, S. (2015, July). Developing Students' Writing Skill by Diary Writing Habit. In International Multidiciplinary Conference on Social Sciences (IMCoSS) (Vol. 1, p. 8).

Safitri, A., \& Nanda, D. S. (2016). THE INFLUENCE OF USING FISHBONE ISHIKAWA TECHNIQUE TO IMPROVE STUDENTS'WRITINGSKILL OF THE FIRST SEMESTER STUDENTS OF ENGLISH EDUCATION STUDY PROGRAM TEACHER TRAINING AND EDUCATION FACULTY UNIVERSITAS BANDAR LAMPUNG. LINGUISTIKA, $7(2)$.

Seidlhofer, B. (2004). Research perspectives on teaching English as a lingua franca. Annual Review of Applied Linguistics, 24, 209-239.

Stern, S. (1991). An Integrated Approach to Literature in ESL/EFL. In Murcia, M. (ed.). Teaching English as a Second or Foreign Language (328-346). Boston: Heinle \& Heinle Publishers.

Susanto, S. (2015). A Systemic Functional Study on the Conversational Structure of an Indonesian Spontaneous Dialogue. English Review: Journal of English Education, 4(1), 122-129.

Susanto, S., \& Nanda, D. S. (2018). Teaching and learning English for visually impaired students: an ethnographic case study. English Review: Journal of English Education, 7(1), 83-92.

Van, T. T. M. (2009). The relevance of literary analysis to teaching literature in the EFL classroom. English Teaching Forum, 3, 2-9.

Ventola, E. (1988) Text Analysis in Operation: A Multiple Approach. In Fawcett, R.P. and Young, D.J. (Eds.) New Developments in Systemic Linguistics. London: Pinter. 52-77. 
Wanner, E., \& Gleitman, L. (1982). Language acquisition: The state of the art. Cambridge: Cambridge University

Press. Yeasmin, N. et.al. (2011). Teaching Language through Literature: Designing Appropriate Classroom Activities. ASA University Review, 5(2), 283-297.

Zhen, C. (2012). Characteristics and Strategies of Literature Teaching in the EFL Context in China. International Journal of Electronics and Communication Engineering, 5(3), 35-43. 